SHORT COMMUNICATION

\title{
Tomato juice as a potential replacement for human serum in germ tube test assay
}

\author{
A. Shiyamalee ${ }^{1, *}$, G.J. Panagoda ${ }^{2}$ and M.R.D.M. Senanayake ${ }^{2}$ \\ ${ }^{1}$ Department of Medical Laboratory Science, Faculty of Allied Health Sciences, University of Peradeniya, Peradeniya, \\ Sri Lanka. \\ ${ }^{2}$ Department of Microbiology, Faculty of Dental Sciences, University of Peradeniya, Peradeniya, Sri Lanka.
}

Received: 21/06/2019 ; Accepted: 06/04/2020

\begin{abstract}
Candida albicans (C. albicans) is the most common opportunistic fungal pathogen often isolated from clinical samples. Traditionally, the differentiation of $C$. albicans from other Candida species is performed through the germ tube test using human serum. The aim of this study was to assess the use of tomato juice of "Thilina" variety for the differentiation of C. albicans from other non albicans species. This study was carried out using 66 Candida isolates including five Candida standards. Candidal suspension (100 $\mu \mathrm{l})$ equals to $0.5 \mathrm{McF}$ arland was mixed with $1 \mathrm{ml}$ of fresh human serum and $1 \mathrm{ml}$ of tomato juice, separately. Test tubes were incubated at $37{ }^{\circ} \mathrm{C}$ and the observations were made at 15 minute intervals for two hours The tomato juice exhibited $97 \%$ sensitivity, $100 \%$ specificity, $97 \%$ positive predictive value, $100 \%$ negative predictive value and higher positive correlation $\left(\mathrm{R}^{2}>0.6\right)$ in producing results. There was no statistically significant difference $(P=0.05)$ in the meantime of initial germ tube production when tomato juice was compared with the routine serum medium. For the first time the study strongly suggests that human serum can be replaced by juice of "Thilina" variety of tomato for the differentiation of $C$. albicans from non albicans species.
\end{abstract}

Keywords: Tomato juice; Candida albicans; Differentiation; Germ tube formation; Human serum.

\section{INTRODUCTION}

Candida albicans (C. albicans) is one of the most frequently isolated yeasts in clinical laboratories (Mayer et al., 2013). The ability of $C$. albicans to infect diverse host niches is supported by a wide range of virulent factors (Calderone et al., 2001; yang, 2003; Kumamoto and Marcelo, 2005). This requires the organism to be differentiated from other Candida species in clinical specimens (Isibor et al., 2005; Cornelius et al., 2018). Although various methods are available for the identification of $C$. albicans, routine identification is based on a few criteria such as growth characteristics, morphology and fermentation (Brooks et al., 2013; Ameen et al.,2017; Sanchez et al.,2017) . Traditionally, the preliminary identification of C. albicans is made through the use of a germ tube test (Sheppard et al., 2008; Greenwood et al., 2012). 95\% of C. albicans is positive while $5 \%$ is negative for germ tube test performed using fresh human serum (Jan et al., 2018). However, $C$. dubliniensis is also capable of producing germ tubes in serum germ tube assay (Moran et al., 2012).

The use of human serum in the traditional germ tube test is cheap but presents a hazard for transmission of infectious diseases and there is also a possibility for false negative results due to the biological inhibitors present in the human serum ( Mattei et al.,2004; Atlay et al., 2017; Mehta et al., 2018). Commercially prepared germ tube medium, which is safe is also available, yet could be unaffordable for countries with limited resources (Sudbery et al., 2004). This warrants investigations for an economically feasible alternative medium for identification of C. albicans. .

Tomato fruit contains beta-carotene, niacin, calcium, lycopene, derivatives of hydroxycinnamic acid, flavonoids, high amount of water and vitamins, specifically A, C, and E. Water, nutrient content and acidic environment $(\mathrm{pH}$ $4.9-6.5$ ) enhance microbial growth, especially of fungi, which degrade the nutrients through enzyme production (Bello et al., 2016; Terna and Simon, 2017). Ghosh et al., (2009) reported that fungi were more active than bacteria in tomato fruit spoilage.

Induction of germ tube production under slightly acidic $\mathrm{pH}$ and the high susceptibility of tomato to fungal diseases as reported in previous studies suggest the possibility of using tomato juice $(\mathrm{pH}=5)$ as a medium for germ tube production by C. albicans (Bello et al., 2016). This study investigates the possibility of using tomato juice from the "Thilina" variety as a low cost, less hazardous alternative to human serum for germ tube test for C. albicans.

\section{MATERIALS AND METHODS}

\section{Tomato (Tomato lycopersicum) variety}

Young, fresh, undamaged fruits of "Thilina" variety of tomato were obtained from Horticultural Crop Research and Development Institute, Gannoruwa, Peradeniya, Sri Lanka. The fresh fruits were collected once a week at the time of harvesting and stored in the refrigerator $\left(20^{\circ} \mathrm{C}\right)$ until used.

\section{Collection of human serum}

Fresh human serum was collected from the Biochemistry 
Laboratory, Teaching Hospital Peradeniya, Kandy, Sri Lanka. Human serum samples $(n=50)$ were collected into a sterile bottle and the fresh serum pool was prepared every day (Matare et al., 2017).

\section{Strain selection}

Standard C. albicans isolate ATCC 10291 was obtained from the Microbiology unit, Medical Research Institute, Colombo, Sri Lanka. Other required Candida isolates were obtained from the culture collection in the Microbiology Laboratory, Division of Microbiology, Faculty of Dental Sciences, University of Peradeniya. Sixty six Candida isolates were used for this study (Standard Candida isolates: C. albicans (ATCC 10231), Candida parapsilosis (ATCC 22019), Candida krusei (ATCC 6258), Candida glabrata (ATCC 90030), Candida tropicalis (ATCC 13803); Clinical Candida isolates: C. albicans - 32, Non C. albicans-29).

\section{Preparation of tomato (Solanum lycopersicum) juice}

Tomatoes were washed thoroughly with sterile distilled water and wiped with $70 \%$ Ethanol. Tomato juice was obtained using the $3 \mathrm{cc}$ sterile needle and syringes and transferred to a sterile glass bottle.

\section{Preparation of Candida cell suspensions}

Candida cell suspensions were prepared immediately before the germ tube assay. A screw-capped test tube with $8 \mathrm{ml}$ distilled water was sterilized by autoclaving at $121{ }^{\circ} \mathrm{C}$ and $15 \mathrm{lb}$ pressure for 15 to 20 minutes. Two to three isolated colonies from a 24-hour Candida culture were smeared in the inner wall of the test tube. Then the colonies were dispersed in distilled water and it was mixed further using a vortex machine (Votex mixer, Lab Tech). The turbidity of the suspension was made equal to that of the $0.5 \mathrm{McF}$ arland standard by adding more inoculum or diluting with sterile distilled water (final cell density ca. $10^{8}$ cells/ ml).

\section{Germ tube assay}

A suspension $(100 \mu \mathrm{l})$ of $C$. albicans clinical isolate with turbidity made equal to that of $0.5 \mathrm{McF}$ arland standard was mixed with $1 \mathrm{ml}$ of human serum as the positive control, with $1 \mathrm{ml}$ of tomato juice as the test and $1 \mathrm{ml}$ of distilled water as the negative control. The test tubes were incubated at $37^{\circ} \mathrm{C}$ for the production of germ tubes. The observations were recorded at 15 minute intervals for

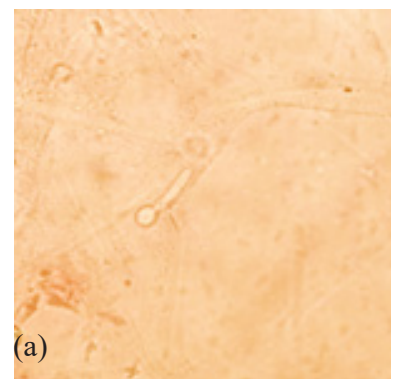

two hours. One drop from each test tube was placed on a sterile glass slide and covered with a clean coverslip. Each slide was observed under light microscope $(x \leqslant$. objective). The presence of germ tubes was noted and the time taken for the initial appearance of germ tubes was noted. Further, germ tube assay was performed on standard C. albicans (ATCC 10231), standard non albicans such as C. parapsilosis (ATCC 22019), C. krusei (ATCC 6258), C. glabrata (ATCC 90030), C. tropicalis (ATCC 13803) and non-Candida clinical isolates. Each experiment was duplicated and repeated three times.

\section{Statistical analysis}

Statistical analysis was done using SPSS version 23 to perform the Paired t test (95\% confidence interval) and Pearson correlation. The sensitivity, specificity, positive predictive value and negative predictive value were also calculated.

$$
\begin{gathered}
\text { Sensitivity }=\frac{\text { True positive }}{\text { True positive }+ \text { False negative }} \times 100 \\
\text { Specificity }=\frac{\text { True negative }}{\text { True negative }+ \text { False positive }} \times 100 \\
\text { Positive predictive value }=\frac{\text { True positive }}{\text { True positive }+ \text { False positive }} \times 100 \\
\text { Negative predictive value }=\frac{\text { True negative }}{\text { True negative }+ \text { False positive }} \times 100
\end{gathered}
$$

\section{RESULTS AND DISCUSSION}

The results showed that 32 out of 33 C. albicans isolates including the standard isolate (ATCC 10231) produced germ tubes in tomato juice while all 33 C. albicans isolates produced germ tubes in the human serum (Figure 1). All the 33 non albicans isolates and four non albicans standards, namely C. parapsilosis ATCC 22019, C. krusei ATCC 6258, C. glabrata ATCC 90030 and C. tropicalis ATCC 13803 failed to produce germ tubes in tomato juice, consistent with the routine human serum method. The mean time taken for the formation of germ tubes for C. albicans clinical isolates in human serum and tomato juice was and minutes, respectively.

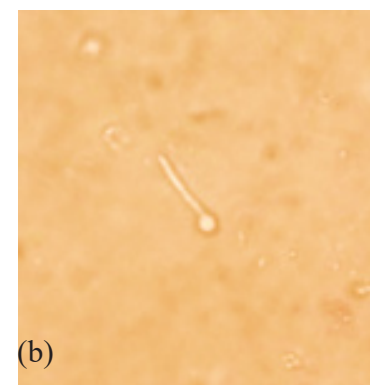

Figure1: Photomicrographs $(\times 40)$ showing germ tube production in tomato juice (a) and in human serum (b). 
Table 1: Germ tube test result for clinical and standard Candida isolates in human serum and tomato juice.

\begin{tabular}{lccc}
\hline & $\begin{array}{c}\text { Number of isolates that } \\
\text { produced germ tubes in } \\
\text { human serum }\end{array}$ & $\begin{array}{c}\text { Number of isolates that failed to } \\
\text { produce germ tubes in human serum }\end{array}$ & Total number \\
\hline $\begin{array}{l}\text { Number of isolates that } \\
\text { produced germ tubes in tomato } \\
\text { juice }\end{array}$ & 32 & 0 \\
$\begin{array}{l}\text { Number of isolates that failed to } \\
\text { produce germ tubes in tomato } \\
\text { juice }\end{array}$ & (False negative) & 33 \\
Total number & 33 & (True negative) & 32 \\
\hline
\end{tabular}

Table 2: Intra species variation in germ tube production of $\boldsymbol{C}$. albicans in human serum and tomato juice.

\begin{tabular}{lcc}
\hline & \multicolumn{2}{c}{ Initial percentage detection of germ tubes (\%) } \\
\cline { 2 - 3 } & Human serum & Tomato \\
\hline 15 minutes & $0 \%$ & $0 \%$ \\
30 minutes & $6.3 \%$ & $3.1 \%$ \\
45 minutes & $18.8 \%$ & $12.5 \%$ \\
60 minutes & $62.5 \%$ & $68.8 \%$ \\
75 minutes & $0 \%$ & $0 \%$ \\
90 minutes & $3.1 \%$ & $3.1 \%$ \\
105 minutes & $3.1 \%$ & $6.3 \%$ \\
120 minutes & $6.3 \%$ & $6.3 \%$ \\
\hline
\end{tabular}

The results showed that, tomato juice alone can induce germ tube formation of $C$. albicans yeast cells with $97 \%$ sensitivity and $100 \%$ specificity (Table 1 ). There is no significant difference in the mean time for the induction of germ tubes between human serum and tomato juice $(P$ $=0.129$ ). According to the statistical analysis the positive predictive value was $97 \%$ and the negative predictive value was $100 \%$.

The time taken for the initiation of germ tube formation varied between 30 minutes and 120 minutes in both pooled human serum and tomato juice. Further, $62.5 \%$ and $68.8 \%$ of $C$. albicans clinical isolates showed germ tube production after one hour in human serum and in tomato juice, respectively. C. albicans isolates have taken different times to produce germ tubes and at the end of 120 minutes all the clinical isolates started to produce germ tubes. This highlights intra species variation in germ tube production within C. albicans (Table 2).

Statistical analysis between the mean time of germ tube production of pooled human sera and tomato juice expressed a $P$ value of $0.129(P>0.05)$ indicating that there was no statistically significant difference in the meantime of germ tube production. This suggests that tomato juice can be used for demonstrating the germ tube production with similar turnaround time as human serum. Pearson correlation $\left(\mathrm{R}^{2}>0.834, P=0.01\right)$ reveals that there is a higher positive correlation between the mean time of human serum and tomato juice in germ tube assay. Hence, according to the Pearson correlation results, human serum can be replaced by tomato juice in the germ tube assay.

\section{CONCLUSION}

Over the years, studies have been conducted to discover a new source for the differentiation of $C$. albicans from non albicans. In the current study, tomato juice assay was used to differentiate C. albicans from other Candida species using 61 clinical isolates and 5 Candida standards including C. albicans, C. parapsilosis, C. krusei, C. glabrata and $C$. tropicalis. The result of tomato juice study showed $97 \%$ sensitivity, $100 \%$ specificity, $100 \%$ positive predictive value, 97\% negative predictive value and higher positive correlation $\left(\mathrm{R}^{2}>0.6\right)$ There was no statistically significant difference $(P=0.129)$ in the meantime taken for initial germ tube production between the tomato juice and the routine human serum medium. The results of the current study revealed that the human serum used in the routine germ tube assay can be replaced by the tomato juice of "Thilina" variety for the differentiation of C. albicans from non albicans species.

\section{ACKNOWLEDGEMENT}

The authors wish to acknowledge the support received from Faculty of Allied Health Sciences and Division of Microbiology, Faculty of Dental Sciences, University of Peradeniya, Sri Lanka. The authors are also grateful to Dr. Pasan Jayasinghe for guidance with the statistical analyses.

\section{DECLERATION OF CONFLICT OF INTEREST}

Authors declare no conflict of interest. 


\section{REFERENCES}

Ameen, F., Moslem, M., Tami, M. A., Ajlan, H. A., Quhtani, N. A., (2017) Identification of Candida species in vaginal flora using conventional and molecular methods. Journal De Mycologie Medicale 3: 364-368

Atalay, M. A., Koc, A. N., Parkan, O. M., Aydemir, G. E. F., Sav, H., (2017) Can serums be replaced by MuellerHinton agar in germ tube test?. Nigerian Journal of Clinical Practice 20: 61-63.

Bello, O. B., Bello, I. S., Aminu, D., Olawuyi, O. J., Balogun, N. B. A., Lawal, A. O., Azeez, A. H., Habib, U., (2016) Antibiotic sensitivity of bacterial and fungal isolates from tomato ( Solanum lycopersicum) fruit. Tropical plant research 3: 112-119.

Brooks, G. F., Carroll, K. C. T., Morse, S. A., Butel, J. S., Mietzner, T. A., (2013) Medical Microbiology. United States: McGraw-Hill Companies Pp 671- 696.

Calderone, R. A., Fonzi, W. A., Virulence factors of $C$. albicans.(2001) Review TRENDS in Microbiology 9: 327-335.

Corneliu, J. C., Nguyen, M. H., (2018) Diagnosing Invasive Candidiasis. Journel of clinical microbiology 56:19091917.

Ghosh, S., Dhammika, H. M. L. P. N., Roberts, D. D., Cooper, J. T., Atkin, A. L., Petro, T. M., Nikerson, K. W., (2009) Arginine-induced germ tube formation in $C$. albicans is essential for escape from murine macrophage line. Infection and immunity 77: 1596-1605.

Greenwood, D., Barer, M., Slack, R., Irving, W., (2012) Medical Microbiology. United Kingdom: Elsevier Ltd Pp 616-640.

Isibor, J. O., Eghubare, A. E., Omoregie, R., (2005) Germ Tube Formation in C. albicans: Evaluation of human and animal sera and incubation stmosphere. Shiraz E-Medical Journal 6: 21-25.

Jan, A., Bashir, G., Qadir, R., Fomda, B. A., Sofia, Hakak, A. Y., (2018) Modified germ tube test : A rapid test for differentian of Candida albicans from Candida dubliniensis. International journal of contemporary medical research 5:15-17.

Kumamoto, C. A., Marcelo, D.V., (2005) Contributions of hyphae and hypha-co-regulated genes to Candida albicans virulence. Cellular Microbiology 7: 15461554.

Matare, T., Nziramasanga, P., Gwanzura, L., Robertsan, V., (2017) Experimental germ Tube induction in Candida albicans: An evaluation of the effect of sodium bicarbonate on morphogenesis and comparison with pooled human serum. Biomed research international 2017: 8-13.

Mattei, A. S., Alves, S. H., Severo, C. B., Guazzelli, L. S., Oliveria, F. M., Severo, L. C., (2014) Use of muller hinton broth and Agar in the germ tube test. Revista do Instituto de Medicina Tropical de Sao Paulo 56: 483485.

Mayer, F. L., Wilson, D., Hube, B., (2013) Candida albicans pathogenicity mechanisms. Virulence 4: 119128.

Moran, G. P., David, C., and Sullivan., (2012) Candida albicans versus Candida dubliniensis: Why is $C$. albicans more pathogenic? International journal of microbiology 2012: 1-7.

Mehta, A., Kumar, M., Bhumbla, U., Anamika, V., Dalal, A. S., (2018) Comparison of different media for germ tube production by Candida albicans; A retrospective study. International journal of current microbiology and applied sciences 7: 819-823.

Sanchez, M. P., Breval, Z. U., Mendez, C. C., Rey, S. G., Mejias, A. R., Mazuelos, E. M., (2017) Candida albicans Germ-Tube Antibody: Evaluation of a New Automatic Assay for Diagnosing Invasive Candidiasis in ICU Patients. Mycopathologia 182: 645-652.

Sheppard, D. C., Locas, M. C., Restieri, C., Laverdiere, M.,(2008) Utility of the Germ Tube Test for Direct Identification of Candida albicans from Positive Blood Culture Bottles. Journal of Clinical Microbiolog 46: 3508-3509.

Sudbery, P., Gow, N., Berman, J., (2004) The distinct morphogenic states of Candida albicans. Trends in Microbiology 12: 317-324.

Terna, T. P., Simon, A., (2017) Biological Control of Some Fungal Pathogens of Tomato (Solanum lycopersicum Mill.) Using Ethanolic Leaf Extracts of Plants. Journal of Environmental and Agricultural Sciences 13: 9-15.

Yang, Y. L., (2003) Virulence factors of Candida species. Journel of Microbial Immunol Infect 36: 223-228. 